\title{
Brucella antibody seroprevalence in Antarctic seals (Arctocephalus gazella, Leptonychotes weddellii and Mirounga leonina)
}

\author{
Silje-Kristin Jensen ${ }^{1,2, *}$, Ingebjørg Helena Nymo $^{1}$, Jaume Forcada ${ }^{3}$, Ailsa Hall ${ }^{2}$, \\ Jacques Godfroid ${ }^{1}$
}

\begin{abstract}
${ }^{1}$ Section for Arctic Veterinary Medicine, Norwegian School of Veterinary Science, Stakkevollveien 23, 9010 Tromsø, Norway; member of the Fram Centre - High North Research Centre for Climate and the Environment, 9296 Tromsø, Norway

${ }^{2}$ Sea Mammal Research Unit, Scottish Oceans Institute, University of St. Andrews, St. Andrews KY16 8LB, UK

${ }^{3}$ British Antarctic Survey, Natural Environment Research Council, High Cross, Madingley Road, Cambridge CB3 0ET, UK
\end{abstract}

\begin{abstract}
Brucellosis is a worldwide infectious zoonotic disease caused by Gram-negative bacteria of the genus Brucella, and Brucella infections in marine mammals were first reported in 1994. A serosurvey investigating the presence of anti-Brucella antibodies in 3 Antarctic pinniped species was undertaken with a protein A/G indirect enzyme-linked immunosorbent assay (iELISA) and the Rose Bengal test (RBT). Serum samples from 33 Weddell seals Leptonychotes weddelli were analysed, and antibodies were detected in 8 individuals (24.2\%) with the iELISA and in 21 $(65.6 \%)$ with the RBT. We tested 48 southern elephant seal Mirounga leonina sera and detected antibodies in 2 animals $(4.7 \%)$ with both the iELISA and the RBT. None of the 21 Antarctic fur seals Arctocephalus gazella was found positive. This is the first report of anti-Brucella antibodies in southern elephant seals. The potential impact of Brucella infection in pinnipeds in Antarctica is not known, but Brucella spp. are known to cause abortion in terrestrial species and cetaceans. Our findings suggest that Brucella infection in pinnipeds is present in the Antarctic, but to date B. pinnipedialis has not been isolated from any Antarctic pinniped species, leaving the confirmation of infection pending.
\end{abstract}

KEY WORDS: Serology · Antarctic fur seal $\cdot$ Weddell seal $\cdot$ Southern elephant seal $\cdot$ Pinniped · Brucella pinnipedialis

Resale or republication not permitted without written consent of the publisher

\section{INTRODUCTION}

Bacteria from the genus Brucella give rise to the world's most common zoonotic disease, brucellosis (Pappas et al. 2006). The main sources of human infection are production animals, and the symptoms in humans are varied and nonspecific. Brucellosis is known to cause abortion and sterility in livestock (Corbel \& Brinley-Morgan 1984) and some wildlife species (Godfroid 2002), including cetaceans (Guzman-Verri et al. 2012). Transmission of Brucella spp. between terrestrial animals usually takes place through contact with aborted infected material and also during breeding and lactation (Corbel \& BrinleyMorgan 1984, Radostits et al. 2000).

In the first reports of Brucella in marine mammals, Ross et al. (1994) reported Brucella infection in 4 harbour seals Phoca vitulina, 2 harbour porpoises Phocoena phocoena and a common dolphin Delphinus delphis in Scotland, and Ewalt et al. (1994) isolated Brucella spp. from a captive bottlenose dolphin Tursiops truncatus in California, USA. In 2007, the pin- 
niped and cetacean isolates were published as new species of the genus Brucella with the names B. pinnipedialis (pinnipeds) and B. ceti (cetaceans) (Foster et al. 2007). Since then there have been several reports on the presence of anti-Brucella antibodies and infection with $B$. pinnipedialis in pinnipeds from most parts of the world (Foster et al. 2002, Nymo et al. 2011). Brucella-associated lesions with isolation of $B$. pinnipedialis from seals has never been recorded, whereas $B$. ceti has been isolated in association with a wide range of lesions in cetaceans, especially in the reproductive and neurological systems (Nymo et al. 2011, Guzman-Verri et al. 2012).

The Antarctic continent is one of the most remote areas of the world and contains up to $50 \%$ or more of the world's pinnipeds, with 6 different species: crabeater seal Lobodon carcinophagus, Antarctic fur seal Arctocephalus gazella, Weddell seal Leptonychotes weddellii, Ross seal Ommatophoca rossi, leopard seal Hydrurga leptonyx and southern elephant seal Mirounga leonina. Relatively little data are available on the abundance of these seals (Laws 1984, Boyd 2009). The first indication of the presence of anti-Brucella antibodies in Antarctic seals was reported in 2000 in 6 out of 17 (35.3\%) Antarctic fur seals and a Weddell seal found at Cape Shirreff and San Telmo Islets on Livingston Island in West Antarctica (Retamal et al. 2000). In addition, 5 out of $12(41.7 \%)$ Weddell seals and 5 out of $86(5.8 \%)$ Antarctic fur seals from Cape Shirreff were found to have anti-Brucella antibodies (Blank et al. 2001, 2002). Weddell seals ( $\mathrm{n}=56$; $97 \%$ ) from the Vestfold Hills in East Antarctica showed a high brucellosis seroprevalence (McFarlane 2009), whereas Weddell seals $(n=66)$ from McMurdo Sound in Antarctica were found to be seronegative (Yochem et al. 2009). Thirteen southern elephant seals have previously been investigated for antibodies against Brucella spp. and all were seronegative (Abalos Pineda et al. 2009). A recent study detected antibodies against Brucella spp. in Weddell seals $(\mathrm{n}=19 ; 37 \%)$, Ross seals $(\mathrm{n}=$ $20 ; 5 \%)$ and crabeater seals $(\mathrm{n}=9 ; 11 \%)$, but not in Antarctic fur seals $(\mathrm{n}=69 ; 0 \%$ ) (Tryland et al. 2012). Antibodies against Brucella spp. have been detected in captive Australian fur seals A. pusillus doriferus and leopard seals (Dawson 2005), and a high seroprevalence has been detected in the wild Australian fur seal population (Lynch et al. 2011a,b), and in wild Australian sea lions Neophoca cinerea (Dawson 2005). No serological evidence of Brucella infection was found in 101 pre-weaned wild New Zealand fur seal pups A. forsteri (Mack- ereth et al. 2005). Importantly, to date the isolation of Brucella spp., which is the only certain diagnosis of brucellosis, has not been documented in any Antarctic species, although several attempts have been reported (Abalos Pineda et al. 2009, McFarlane 2009, Lynch et al. 2011a,).

Evidence of the zoonotic potential of the marine mammal brucellae is shown by 3 naturally acquired human cases of infection by Brucella ceti-similar strains (Sohn et al. 2003, McDonald et al. 2006, Whatmore et al. 2008). Two of the naturally infected patients were from Peru (Sohn et al. 2003), and 1 patient was from New Zealand (McDonald et al. 2006), indicating the possible presence of marine mammal brucellae in the southern hemisphere. The 3 marine mammal brucellae strains (or their DNA) isolated from human patients showed the unusual sequence type 27 (ST27). ST27 has only previously been recovered from a bottlenose dolphin foetus, which came from a region where few isolates have been tested (Whatmore et al. 2008). ST27 differed from the strain isolated in a single case of laboratory-acquired Brucella infection (Brew et al. 1999, Whatmore et al. 2008), and also from most strains isolated from marine mammals from other areas (Groussaud et al. 2007, Whatmore et al. 2007). There are no reports of B. pinnipedialis occurring in humans.

The aim of this study was to further investigate the presence of antibodies against Brucella spp. in Weddell seals, Antarctic fur seals and southern elephant seals using a protein A/G indirect enzyme-linked immunosorbent assay (iELISA) and the Rose Bengal test (RBT).

\section{MATERIALS AND METHODS}

\section{Sampling procedure}

Blood samples from Weddell seals were collected from lactating females $(\mathrm{n}=24)$ and their pups $(\mathrm{n}=9)$ at a breeding colony at Hutton Cliffs, East Antarctica, during the Antarctic spring, October to December 2003. The animals were sedated with a 1:1 mixture of tiletamine and zolazepam as previously described (Wheatley et al. 2006). The blood samples were collected from the extradural vein using the Vacutainer system (Becton Dickinson) into plain tubes. Samples were centrifuged in the field and serum was collected and stored at $-20^{\circ} \mathrm{C}$ until analysis. The sampling was performed as a collaboration between Macquarie University, Australia, the University of 
Otago, New Zealand, and the University of St Andrews, UK, to investigate maternal fitness effects on health and immunity, and breeding strategies in Weddell seals (Wheatley et al. 2008).

Freshly dead adult Antarctic fur seal males, dead from unknown causes $(n=21)$, were obtained at the breeding colony of Freshwater Inlet on Bird Island, South Georgia, in December 2008. Necropsies were carried out in situ, and approximately $2 \mathrm{ml}$ of blood were collected from the aorta and preserved in $1.5 \mathrm{ml}$ eppendorf tubes at $-20^{\circ} \mathrm{C}$.

Blood samples were obtained from southern elephant seals $(n=37)$ from Macquarie Island, Pacific Ocean, during their annual moult in 2000 and on South Georgia $(\mathrm{n}=11)$ in 2005. Animals were sedated with a 1:1 mixture of tiletamine and zolazepam (Zoletil ${ }^{\circledR}$ 100, Virbac; or Telazol ${ }^{\circledR}$, Wildlife Pharmaceuticals) at an approximate dose rate of 0.2 to $0.4 \mathrm{mg} \mathrm{kg}^{-1}$, and blood samples were collected from the extradural vein using the Vacutainer system into plain tubes. Samples were either centrifuged or left to settle, and the serum was collected and stored at $-20^{\circ} \mathrm{C}$ until processed. The sampling at Macquarie Island was performed as part of a collaborative study between the Australian Antarctic Division, Australia, the University of Tasmania, Australia, and the University of St Andrews, UK, investigating energetics and diving behaviour (Biuw et al. 2003). The study on South Georgia was part of the larger international study 'Marine Mammals Exploring the Oceans Pole to Pole', MEOP (Biuw et al. 2007).

\section{Serological methods}

Serum samples were tested for antibodies against Brucella spp. with the RBT, with Brucella abortus Weybridge 99 strain as an antigen (IDEXX Laboratories, Pourquier) according to the manufacturer's instructions (OIE 2008). An iELISA previously shown to yield results in coherence with a panel of serological tests when utilized on hooded seal Cystophora cristata serum samples was also used (Nymo et al. 2013). The mean optical density (OD) of duplicate wells was expressed as a percentage of the reactivity of a positive serum from a bacteriology-positive hooded seal ([OD sample/OD positive control] $\times 100$ ) $=$ percent positivity $(\% \mathrm{P})$. The cutoff for the iELISA was calculated by the mean value of 125 negative hooded seal serum samples (negative in the Complement Fixation Test, the Slow Agglutination of Wright [SAW EDTA] and the RBT) plus 2.58 standard devia- tions, providing a cutoff for the iELISA of $73.6 \% \mathrm{P}$ (Nymo et al. 2013).

\section{Data analysis}

Linear regression analysis was used to evaluate the correlation between seropositivity and age for the Weddell seal data. Age was analysed as a categorical variable with pup and adult as the 2 age levels. A $\mathrm{p}$-value of $<0.05$ was considered significant. Analyses were performed using $\mathrm{R}$ software ( $\mathrm{R}$ Development Core Team 2007).

\section{RESULTS}

Antibodies against Brucella spp. were detected with the iELISA in serum from 8 out of 33 Weddell seals $(24.2 \%)$ and with the RBT in 21 out of 32 Weddell seals $(65.6 \%$; Table 1$)$. All of the iELISA positive samples were also RBT positive. The seroprevalence was found to be higher among adult Weddell seals $(88.9 \%, \mathrm{p}<0.05)$, whereas all pups were found to be seronegative with the iELISA. Three of the seropositive adult Weddell seals were females with seronegative nursing pups.

Two out of 48 southern elephant seals ( $4.7 \%)$ were seropositive (the same 2 individuals tested positive with both the iELISA and the RBT; Table 1). It was not appropriate to test for differences in prevalence by age due to the very small number of positive samples, but the 2 positive elephant seals were a subadult from South Georgia and a pup ( $<1$ yr old) from Macquarie Island.

Table 1. Brucella spp. seropositive rates (\%) among pinnipeds from Antarctica, presented by species, method and age (pups = age $<1 \mathrm{yr}$; subadults/adults = age $\geq 1 \mathrm{yr}$ ), with sample sizes in parentheses. RBT: Rose Bengal test; iELISA: indirect ELISA; na: not applicable

\begin{tabular}{|lcccc|}
\hline Species & Method & $\begin{array}{c}\text { Total } \\
\%(\mathrm{n})\end{array}$ & $\begin{array}{c}\text { Pups } \\
\%(\mathrm{n})\end{array}$ & $\begin{array}{c}\text { Subadults/ } \\
\text { adults \% (n) }\end{array}$ \\
\hline Weddell seal & RBT $^{\mathrm{a}}$ & $65.6(32)$ & $37.5(8)$ & $75.0(24)$ \\
iELISA & $24.2(33)$ & $0.0(8)$ & $32.0(25)$ \\
Antarctic & RBT $^{\mathrm{a}}$ & na & na & na \\
fur seal & iELISA & $0.0(21)$ & $-(0)$ & $0.0(21)$ \\
Southern & RBT & $4.7(48)$ & $2.7(37)$ & $9.1(11)$ \\
elephant seal & iELISA & $4.7(48)$ & $2.7(37)$ & $9.1(11)$ \\
a The serum samples from all Antarctic fur seals and 1 \\
Weddell seal could not be analysed with the RBT due to \\
the poor quality of the samples \\
\hline \multicolumn{7}{l}{} \\
\hline
\end{tabular}


All Antarctic fur seals examined were seronegative (Table 1).

\section{DISCUSSION}

Our results, together with previous studies, suggest that seals are probably exposed to Brucella spp. in the Antarctic. Two of the 3 pinniped species tested had anti-Brucella antibodies. Both seropositive species belong to the family Phocidae. The Antarctic fur seal is the only species in our study from the family Otariidae, and we found no seropositive animals from this species. Our study, like previous studies, indicates that this otariid shows a low prevalence of antibodies against Brucella spp. (Retamal et al. 2000, Abalos Pineda et al. 2009, Tryland et al. 2012). Although $B$. pinnipedialis has been isolated in many different Phocidae species (Nymo et al. 2011), isolation from otariids has only been reported once in California sea lions Zalophus californianus, and the characterization of these strains is still pending (Goldstein et al. 2009).

Serological cross-reactions and false positives are major problems when detecting anti-Brucella antibodies by serological methods. In cattle, most of the problems arise from an immune response of the animal to another microorganism which shares epitopes with brucellae O-polysaccharide (Corbel 1985), Yersinia enterocolitica O:9 being the most important (Caroff et al. 1984). Some other known possible cross-reacting agents are Francisella tularensis, Salmonella group $\mathrm{N}$ (O:30), Escherichia coli O:157 and O:116, Stenotrophomonas maltophilia and Vibrio cholerae (Alton et al. 1988). In a large study of several species of seals from the North Atlantic Ocean, all animals seropositive for brucellae were seronegative for $Y$. enterocolitica $\mathrm{O}: 9$, and $Y$. enterocolitica O:9 could not be isolated from various tissues of 62 animals (Tryland et al. 1999), indicating that crossreactivity with $Y$. enterocolitica O:9 was not the likely cause of seropositivity in these animals. Y. enterocolitica has never been isolated in Antarctica (Gasper \& Watson 2001), but we cannot rule out the possibility that $Y$. enterocolitica O:9, or other cross-reacting bacteria, are potential confounding factors in Antarctic pinniped tests. Seroprevalences previously reported in Weddell seals from the Vestfold Hills have been as high as $97.0 \%$ ( $\mathrm{n}=57$; McFarlane 2009), which might indicate a cross-reacting agent, because a brucellosis enzootic situation where virtually all animals in the population have been exposed to Brucella spp. has never been described.
Presence of antibodies may suggest exposure to brucellae at some point in time, but not necessarily an active infection, and the ability of a serological test to detect antibodies is also dependent on the time post-infection (Godfroid et al. 2002). A recent study in a declining Alaskan harbour seal population reported an assay-dependent difference in apparent exposure rates to Brucella spp. when using the brucellosis card test, the $B$. abortus plate test, a competitive ELISA using an antigen derived from Brucella isolated from a harbour seal, a B. ovis ELISA as well as a $B$. canis rapid slide agglutination test (Hueffer et al. 2013). A seemingly higher seroprevalence detected using the RBT, as in the present study, could be explained by the use of lipemic serum or by the conversion of fibrinogen to fibrin, which can lead to false positive results (Nielsen et al. 2005). The much higher seroprevalence detected with the RBT than with the iELISA in this study, reinforce the need for a careful interpretation of exposure and exposure rates to Brucella spp. in pinnipeds. A previous study on hooded seals (Nymo et al. 2013) utilizing the same iELISA as in the present study and the RBT showed a Cohen's kappa value (to assess pairwise coherence) between the 2 tests of 0.52 . The PrA/G iELISA yielded a seroprevalence of $23.8 \%$ (41/172), while the seroprevalence found with the RBT was $9.9 \%$ (17/172; Nymo et al. 2013). This further strengthens the evidence of sample quality affecting the outcome of the RBT, as some of the serum samples used in the present study were from animals found dead, and thus of poor quality, and the sera from lactating pups were highly lipemic, while the hooded seal sera in the previous study were of good quality (I. H. Nymo pers. obs.). The elephant seal sera included in our study - for which the iELISA and RBT results were in accordance with each other-were of good quality.

Hutton Cliffs is an important breeding site for Weddell seals in McMurdo Sound. A previous serological investigation from 1996 to 1999 for anti-Brucella antibodies in Weddell seals from this area resulted in no seropositive animals ( $\mathrm{n}=81$; Yochem et al. 2009). We found a relatively high seroprevalence in this population. The reason for the discrepancy between our study and the study of Yochem et al. (2009), which are only separated by $4 \mathrm{yr}$, is unknown. The Weddell seal population overall is stable with regards to population size (McFarlane 2009, Yochem et al. 2009), indicating that the high prevalence of possible Brucella spp. seropositive animals is for now not negatively affecting reproduction. This is in accordance with previous observations related to the isolation of 
B. pinnipedialis in the absence of any associated gross lesions in different seal species (Nymo et al. 2011).

The southern elephant seal population at Macquarie Island reaches sexual maturity later than those from South Georgia and shows lower survival and growth rates. Survival of first-year seals has in periods been dramatically low, and the population has declined from 183000 in 1949 to 76000 in 2001 (Hindell et al. 1994, Australian Antarctic Division unpublished data). Why the population is declining is still unknown, but low juvenile survival has been suggested as a factor (Hindell 1991), as has food availability (McMahon et al. 2003). Approximately half of the global adult population of southern elephant seals breeds at South Georgia, and the population numbers continue to be stable (McCann \& Rothery 1988, Boyd et al. 1996). To our knowledge, no previous assessments have been made of the Brucella-serostatus of this population or the South Georgia population.

California sea lions commonly suffer from reproductive failure, including abortions and premature live births. Prior investigation showed the presence of Brucella spp. DNA in 3 out of 59 of the investigated placentae, and 2 of the placentae were also culture positive, but lacked any Brucella-associated histological lesions (Goldstein et al. 2009). The lack of histopathology and lack of isolation of Brucella spp. from any of the 67 aborted or live-born premature sea lion pups included in the study suggests that Brucella spp. had no role in the abortions or premature pup deliveries. Goldstein et al. (2009) concluded that there were multiple aetiologies of abortion and premature parturition in the sea lions, including domoic acid. Abortions are also commonly observed in Australian fur seals (McKenzie et al. 2005), and a high prevalence of Brucella spp. seropositive adult females $(56.8 \%)$ has been detected in this species (Lynch et al. 2011b), while the seroprevalence among juveniles is somewhat lower $(37.8 \%)$ and the seroprevalence among pups is close to $0(1 / 301$; Lynch et al. 2011a). Lesions seen in 4 aborted foetuses were consistent with bacterial infection, but Brucella spp. could not be detected by bacteriology or PCR in any of the 39 aborted fetuses and 11 placentae investigated. The absence of detection of Brucella spp. did not support the involvement of Brucella spp. in these abortions (Lynch et al. 2011a).

Altogether, the results of our study and previous studies performed in Antarctic seals suggest that Brucella spp. might be present in the Antarctic. It is important to stress that up to date, Brucella spp. have never been isolated from any Antarctic seal species, although attempts have been reported (Abalos Pineda et al. 2009, McFarlane 2009, Lynch et al. 2011a). Thus the question of whether Brucella spp. occurs in seals in the Antarctic ecosystem still remains to be answered. Further studies aimed at isolating the bacteria should be performed to determine if Brucella spp. is present in Antarctic seals, as well as establishing the potential health impact of the disease.

Acknowledgements. We thank all fieldworkers in connection with the British Antarctic Survey, Australian Antarctic Division and the University of St. Andrews that took part in collecting data for this study. We also thank Chris Morris for his constructive comments on the manuscript. S.K.J., I.H.N. and J.G. designed the study. S.K.J. and I.H.N. did the serology laboratory work. J.F. and A.H. collected samples in Antarctica. S.K.J. did the statistics. S.K.J. and I.H.N. did the main work with the manuscript while J.F., A.H. and J.G. gave advice in drafting the manuscript and revised it critically. All authors read and approved the final manuscript.

\section{LITERATURE CITED}

Abalos Pineda P, Blank Hidber O, Torres Navarro D, Torres Castillo D, Valdenegro Vega V, Retamal Merion P (2009) Brucella infection in marine mammals in Antarctica. Vet Rec 164:250

Alton GG, Jones LM, Angus RD, Verger JM (1988) Techniques for the brucellosis laboratory. Institut National de la Recherche Agronomique, Paris

Biuw M, McConnell B, Bradshaw CJA, Burton H, Fedak M (2003) Blubber and buoyancy: monitoring the body condition of free-ranging seals using simple dive characteristics. J Exp Biol 206:3405-3423

Biuw M, Boehme L, Guinet C, Hindell M and others (2007) Variations in behavior and condition of a Southern Ocean top predator in relation to in situ oceanographic conditions. Proc Natl Acad Sci USA 104:13705-13710

Blank O, Retamal P, Abalos P, Torres D (2001) Additional data on anti-Brucella antibodies in Arctocephalus gazella from Cape Shirreff, Livingston Island, Antarctica. CCAMLR Sci 8:147-154

Blank O, Retamal P, Abalos P, Torres D (2002) Detection of anti-Brucella antibodies in Weddell seals (Leptonychotes weddellii) from Cape Shirreff, Antarctica. Arch Med Vet 34:117-122 (in Spanish with English abstract)

Boyd IL (2009) Antarctic marine mammals. In: Perrin WF, Wursig B, Thewissen JGM (eds) Encyclopedia of marine mammals, 2nd edn. Academic Press, San Diego, CA, p 42-48

Boyd IL, Walker TR, Poncet J (1996) Status of southern elephant seals in South Georgia. Antarct Sci 8:237-244

Brew SD, Perrett LL, Stack JA, MacMillan AP, Staunton NJ (1999) Human exposure to Brucella recovered from a sea mammal. Vet Rec 144:483

Caroff M, Bundle DRB, Perry MB (1984) Structure of the 0 -chain of the phenol-phase soluble cellular lipopolysaccharide of Yersinia enterocolitica serotype 0:9. Eur J Biochem 139:195-200 
Corbel MJ (1985) Recent advances in the study of Brucella antigens and their serological cross-reactions. Vet Bull 55:927-942

Corbel MJ, Brinley-Morgan WJ (1984) Genus Brucella Meyer and Shaw 1920. In: Krieg NR, Hold JG (eds) Bergey manual of systematic bacteriology, Vol 1, 2nd edn. Williams and Wilkins, Baltimore, MD, p 377-388

Dawson CE (2005) Anti-Brucella antibodies in pinnipeds of Australia. Microbiol Aust 26:87-89

Ewalt DR, Payeur JB, Martin BM, Cummins DR, Miller WG (1994) Characteristics of a Brucella species from a bottlenosed-dolphin (Tursiops truncatus). J Vet Diagn Invest 6: 448-452

Foster G, MacMillan AP, Godfroid J, Howie F and others (2002) A review of Brucella sp. infection of sea mammals with particular emphasis on isolates from Scotland. Vet Microbiol 90:563-580

> Foster G, Osterman BS, Godfroid J, Jacques I, Cloeckaert A (2007) Brucella ceti sp. nov. and Brucella pinnipedialis sp. nov. for Brucella strains with cetaceans and seals as their preferred hosts. Int J Syst Evol Microbiol 57: 2688-2693

Gasper PW, Watson RP (2001) Plague and yersiniosis. In: Williams ES, Barker IK (eds) Infectious diseases of wild mammals, 3rd edn. Iowa State University Press, Ames, IA, p 313-329

Godfroid J (2002) Brucellosis in wildlife. Rev Sci Tech Off Int Epizoot 21:277-286

Godfroid J, Saegerman C, Wellemans V, Walravens K and others (2002) How to substantiate eradication of bovine brucellosis when aspecific serological reactions occur in the course of brucellosis testing. Vet Microbiol 90: 461-477

Goldstein T, Zabka TS, Delong RL, Wheeler EA and others (2009) The role of domoic acid in abortion and premature parturition of California sea lions (Zalophus californianus) on San Miguel Island, California. J Wildl Dis 45: 91-108

Groussaud P, Shankster SJ, Koylass MS, Whatmore AM (2007) Molecular typing divides marine mammal strains of Brucella into at least three groups with distinct host preferences. J Med Microbiol 56:1512-1518

> Guzman-Verri C, Gonzalez-Barrientos R, Hernandez-Mora G, Morales JA, Baquero-Calvo E, Chaves-Olarte E, Moreno E (2012) Brucella ceti and brucellosis in cetaceans. Front Cell Infect Microbiol 2:1-22

Hindell MA (1991) Some life history parameters of a declining population of elephant seals, Mirounga leonina. J Anim Ecol 60:119-134

Hindell MA, Slip DJ, Burton HR (1994) Possible causes of the decline of southern elephant seal populations in the southern Pacific and southern Indian Oceans. In: Le Boeuf BJ, Laws RM (eds) Elephant seals: population ecology, behavior, and physiology. University of California Press, Berkeley, CA, p 66-83

> Hueffer K, Gende S, O'Hara T (2013) Assay dependence of Brucella antibody prevalence in a declining Alaskan harbor seal (Phoca vitulina) population. Acta Vet Scand 55:2

Laws RM (1984) A decade of research on Antarctic and subAntarctic seals: introduction to the colloquium. S Afr J Sci 80:25-26

Lynch M, Duignan PJ, Taylor T, Nielsen O, Kirkwood R, Gibbens J, Arnould JP (2011a) Epizootiology of Brucella infection in Australian fur seals. J Wildl Dis 47:352-363 Lynch M, Nielsen O, Duignan PJ, Kirkwood R, Hoskins A,
Arnould JP (2011b) Serologic survey for potential pathogens and assessment of disease risk in Australian fur seals. J Wildl Dis 47:555-565

Mackereth GF, Webb KM, O'Keefe JS, Duignan PJ, Kittelberger R (2005) Serological survey of pre-weaned New Zealand fur seals (Arctocephalus forsteri) for brucellosis and leptospirosis. NZ Vet J 53:428-432

McCann TS, Rothery P (1988) Population size and status of the southern elephant seal (Mirounga leonina) at South Georgia, 1951-85. Polar Biol 8:305-309

McDonald WL, Jamaludin R, Mackereth G, Hansen M and others (2006) Characterization of a Brucella sp. strain as a marine-mammal type despite isolation from a patient with spinal osteomyelitis in New Zealand. J Clin Microbiol 44:4363-4370

McFarlane RA (2009) Health assessment and diseases of the Weddell seal, Leptonochotes weddelli, in Vestfold Hills, East Antarctica. In: Kerry KR, Riddle MJ (eds) Health of Antarctic wildlife: a challenge for science and policy, 1st edn. Springer, New York, NY, p 139-166

McKenzie J, Parry LJ, Page B, Goldsworthy SD (2005) Estimation of pregnancy rates and reproductive failure in New Zealand fur seals (Arctocephalus forsteri). J Mammal 86:1237-1246

McMahon CR, Burton HR, Bester MN (2003) A demographic comparison of two southern elephant seal populations. J Anim Ecol 72:61-74

> Nielsen O, Nielsen K, Braun R, Kelly L (2005) A comparison of four serologic assays in screening for Brucella exposure in Hawaiian monk seals. J Wildl Dis 41:126-133

Nymo IH, Tryland M, Godfroid J (2011) A review of Brucella infection in marine mammals, with special emphasis on Brucella pinnipedialis in hooded seal (Cystophora cristata). Vet Res 42:93

Nymo IH, Godfroid J, Aasbakk K, Larsen AK, das Neves CG, Rødven R, Tryland M (2013) A protein A/G indirect ELISA for the detection of anti-Brucella antibodies in Arctic wildlife. J Vet Diagn Invest 25:369-375

OIE (World Organisation for Animal Health) (2008) Bovine brucellosis. OIE manual of diagnostic tests and vaccines for terrestrial animals, 6th edn. Office International des Epizooties, Paris, p 1-35

Pappas G, Papadimitriou P, Akritidis N, Christou L, Tsianos EV (2006) The new global map of human brucellosis. Lancet Infect Dis 6:91-99

R Development Core Team (2007) R: a language and environment for statistical computing. R Foundation for Statistical Computing, Vienna

Radostits OM, Gay CC, Blood DC, Hinchcliff KW (2000) Diseases caused by Brucella spp. In: Radostits OM, Gay CC, Blood DC, Hinchcliff KW (eds) Veterinary medicine. A textbook of the diseases of cattle, sheep, pigs, goats and horses, 9th edn. Elsevier Limited, Edinburgh, p 867-882

Retamal P, Blank O, Abalos P, Torres D (2000) Detection of anti-Brucella antibodies in pinnipeds from the Antarctic territory. Vet Rec 146:166-167

Ross HM, Foster G, Reid RJ, Jahans KL, MacMillan AP (1994) Brucella species infection in sea-mammals. Vet Rec 134:359

Sohn AH, Probert WS, Glaser CA, Gupta N and others (2003) Human neurobrucellosis with intracerebral granuloma caused by a marine mammal Brucella spp. Emerg Infect Dis 9:485-488

Tryland M, Kleivane L, Alfredsson A, Kjeld M, Arnason A, Stuen S, Godfroid J (1999) Evidence of Brucella infection 
in marine mammals in the North Atlantic Ocean. Vet Rec 144:588-592

Tryland M, Nymo IH, Nielsen O, Norøy ES and others (2012) Serum chemistry and antibodies against pathogens in Antarctic fur seals, Weddell seals, crabeater seals, and Ross seals. J Wildl Dis 48:632-645

- Whatmore AM, Perrett LL, MacMillan AP (2007) Characterisation of the genetic diversity of Brucella by multilocus sequencing. BMC Microbiol 7:34

Whatmore AM, Dawson CE, Groussaud P, Koylass MS and others (2008) Marine mammal Brucella genotype associated with zoonotic infection. Emerg Infect Dis 14: $517-518$

Editorial responsibility: Michael Moore, Woods Hole, Massachusetts, USA
Wheatley KE, Bradshaw CJA, Harcourt RG, Davis LS, Hindell MA (2006) Chemical immobilization of adult female Weddell seals with tiletamine and zolazepam: effects of age, condition and stage of lactation. BMC Vet Res 2:8

Wheatley KE, Bradshaw CJ, Harcourt RG, Hindell MA (2008) Feast or famine: evidence for mixed capitalincome breeding strategies in Weddell seals. Oecologia 155:11-20

Yochem PK, Stewart BC, Gelatt TS, Siniff DB (2009) Health assessment of Weddell seals, Leptonychotes weddellii, in McMurdo Sound, Antarctica. In: Kerry KR, Riddle MJ (eds) Health of Antarctic wildlife: a challenge for science and policy. Springer, New York, NY, p 123-138

Submitted: April 8, 2013; Accepted: June 17, 2013

Proofs received from author(s): August 12, 2013 